\title{
Pediatric patients with RASopathy- associated hypertrophic cardiomyopathy: the multifaceted consequences of PTPN11 mutations
}

\author{
Giulio Calcagni ${ }^{1 *}$ (D), Maria Cristina Digilio², Bruno Marino ${ }^{3}$ and Marco Tartaglia $^{2}$
}

\begin{abstract}
The concomitant occurrence of hypertrophic cardiomyopathy and congenital heart defect in patients with RASopathies has previously been reported as associated to a worse clinical outcome, particularly closed to cardiac surgery. Different mechanisms of disease have been demonstrated to be associated with the two classes of PTPN11 mutations underlying Noonan syndrome and Noonan syndrome with multiple lentigines (also known as LEOPARD syndrome). Although differential diagnosis between these two syndromes could be difficult, particularly in the first age of life, we underline the relevance in discriminating these two disorders in terms of affected signaling pathway to allow an effective targeted pharmacological treatment.
\end{abstract}

Keywords: PI3K-AKT-mTOR, MAPK, Hypertrophic cardiomyopathy, RASopathy

\section{Dear Editor,}

We read with interest a recent research by Chen and colleagues [1] reporting on the clinical and mutation profiles of pediatric patients with RASopathy-associated hypertrophic cardiomyopathy (HCM). In this manuscript, the authors described the mutation spectrum causally linked to Noonan syndrome (NS) (MIM PS163950) and clinically related disorders, and the associated clinical outcome, based on a pediatric cohort of 47 affected subjects. An exhaustive genotype-phenotype correlation was reported. Particularly, the data allowed the authors to emphasize further the relevant contribution of the concomitant occurrence of congenital cardiac defects (CHDs) and left ventricular outflow tract obstruction (LVOTO) to the worse outcome of these patients. The authors also reported that patients with a diagnosis of NS based on clinical criteria and carrying two specific missense mutations in PTPN11 (c1417A > C, p.Q506P; c1528C > G, p.Q510E) showed an early-

\footnotetext{
* Correspondence: giulio.calcagni@opbg.net

${ }^{1}$ Cardiology Unit, Department of Pediatric Cardiology and Cardiac Surgery, Bambino Gesù Children's Hospital and Research Institute, Viale di San Paolo 15, 00146 Rome, Italy

Full list of author information is available at the end of the article
}

onset presentation of HCM and a worse clinical outcome. Indeed, out of this subgroup of eleven patients, three of them (p.Q506P, $N=1$; p.Q510E, $N=2$ ) died within 6 months from birth.

We agree with Chen and colleagues that the cooccurrence of HCM and CHDs is generally associated to a worse outcome in patients with RASopathies. Indeed, these patients may show a rapid progression of HCM and this can lead to early cardiac failure. These data are also in line with other recently published studies [2-4]. In particular, our experience confirms that a worse clinical outcome is strictly closed to complex cardiac surgery [2]. However, we would point out that the biochemical/ functional behavior of PTPN11 mutations at codons 510 (including c. $1528 \mathrm{C}>\mathrm{G}$ ) and 506 is drastically different from what observed for NS-causing PTPN11 mutations. Specifically, the former cause defective protein phosphatase activity and differentially affect intracellular signaling [5-7]. Consistent with their distinctive consequences on SHP2 function and signal transduction, these mutations do not cause NS but underlie Noonan syndrome with multiple lentigines (NSML), previously known as LEOPARD syndrome (MIM PS151100), a disorder similar but distinct from NS. NSML-associated 
PTPN11 mutations cluster within or close to the active site of the phosphatase, which explains their dramatic impact on phosphatase activity when compared with wild-type SHP2 and NS-causing PTPN11 mutations [5, 8 , 9]. It should be noted that the presence of cutaneous manifestations as café-au-lait spots and multiple lentigines, which represent a distinctive feature of NSML, develop with age and do not generally occur in infancy. Based on this consideration, the absence of lentigines during infancy should not be used to exclude a diagnosis of NSML. HCM is an additional common complication of NSML. Differently from what reported by Chen and colleagues [1], it is now well-established, and also in line with previous reports [10], that c.1528C > G (p.Q510E) in PTPN11 is strictly associated to NSML. Review of published cases carrying the c. $1528 \mathrm{C}>\mathrm{G}$ missense change documents that most of the patients have a clinical diagnosis of NSML syndrome (Table 1) [11-14].
Notably, two among the three reported patients classified as having NS presented with HCM associated with deafness, a clinical feature characteristic for NSML (Table 1) [15-17]. In regard to c.1529A > C and c. 1530 $\mathrm{G}>\mathrm{C}$, also involving codon 510 of PTPN11, it should be noted that all of them have been reported in patients diagnosed as having NSML syndrome (Table 1) [18-21].

While NS and NSML are genetic conditions with overlapping features, and clinicians experienced with these syndromes are aware of the difficulty in discriminating between these two disorders particularly in the first years of age $[11,22]$, we firmly believe that it is important to properly discriminate NSML from NS to allow a more effective patient management and a future personalized pharmacological treatment of the evolutive complications in these patients. Indeed, it is important to consider that different mechanisms of disease have been demonstrated to be associated with the two classes of

Table 1 Literature reports of patients carrying mutation at codon 510 of PTPN11 gene

\begin{tabular}{|c|c|c|c|c|}
\hline Mutation & Age at observation & Reported clinical diagnosis & Clinical features specific for NS-ML & Reference \\
\hline c.1529A > C; p.Q510P & Adult & NS-ML & Lentigines & Keren et al., 2004 \\
\hline c.1529A > C; p.Q510P & 12 years & NS-ML & $\begin{array}{l}\text { Deafness } \\
\text { Lentigines } \\
\text { Café-au-lait spots } \\
\text { Heart defect and ECG anomalies }\end{array}$ & Keren et al., 2004 \\
\hline c.1529A > C; p.Q510P & 25 years & NS-ML & $\begin{array}{l}\text { Deafness } \\
\text { Lentigines } \\
\text { Café-au-lait spots } \\
\text { PVS }\end{array}$ & Keren et al., 2004 \\
\hline c.1528C > G; p.Q510E & 14 months & NS & $\begin{array}{l}\mathrm{HCM} \\
\text { Deafness }\end{array}$ & Takahashi et al., 2005 \\
\hline c.1529A > C; p.Q510P & Adult & NS-ML & Lentigines & Kalidas et al., 2005 \\
\hline c.1529A > C; p.Q510P & Adult & NS-ML & $\begin{array}{l}\text { Deafness } \\
\text { Lentigines }\end{array}$ & Kalidas et al., 2005 \\
\hline c.1529A > C; p.Q510P & 1 year & NS-ML & PVS, ASD, ECG anomalies & Kalidas et al., 2005 \\
\hline c.1528C > G; p.Q510E & 2 years & NS-ML & $\begin{array}{l}\text { HCM } \\
\text { Café-au lait spots } \\
\text { Lentigines }\end{array}$ & Digilio et al., 2006 \\
\hline c.1528C > G; p.Q510E & 2 years & NS-ML & $\begin{array}{l}\text { HCM } \\
\text { Café-au-lait spots }\end{array}$ & Digilio et al., 2006 \\
\hline c.1528C > G; p.Q510E & 2 months & NS & $\mathrm{HCM}$ & Faienza et al., 2009 \\
\hline c.1528C > G; p.Q510E & 37 years & NS-ML & $\begin{array}{l}\text { HCM } \\
\text { Lentigines } \\
\text { Deafness }\end{array}$ & Lehmann et al., 2009 \\
\hline c.1528C > G; p.Q510E & 5 years & NS & $\begin{array}{l}\text { HCM, PVS } \\
\text { Deafness }\end{array}$ & Derbent et al., 2010 \\
\hline c.1529A > C; p.Q510P & 4 years & NS or NS-ML & Café-au-lait spot & Brasil et al., 2010 \\
\hline c.1528C > G; p.Q510E & infant & NS-ML & $\mathrm{HCM}$ & Ganigara et al., 2011 \\
\hline c. $1530 \mathrm{G}>$ C; p.Q510H & 38 years & NS-ML & $\begin{array}{l}\text { HCM, PVS, ASD } \\
\text { Lentigines } \\
\text { Cafe-au-lait spots }\end{array}$ & Wakabayashi et al., 2011 \\
\hline c.1528C > G; p.Q510E & 20 months & NS-ML & $\begin{array}{l}\text { HCM } \\
\text { Deafness }\end{array}$ & Hahn et al., 2015 \\
\hline
\end{tabular}


PTPN11 mutations underlying NS and NSML. On one hand, we have hyperactive mutants promoting upregulation of MAPK signaling (NS-causing mutations), which can effectively be controlled by the use of inhibitors of signal transducers functioning in this cascade (e.g., MEK1 inhibitors) [23, 24]. On the other hand, we have hypomorphic mutants that result in enhanced signal flow through the PI3K-AKT-MTOR pathway (NSMLcausing mutations). In this case, inhibitors targeting this specific cascade (e.g., AKT inhibitors, rapamycin analogs) are required to counterbalance and treat evolutive complications of NSML, including HCM $[14,25,26]$. On this argument, Wang et al. [26] reported an in vivo study suggesting that the AKT inhibitor ARQ 092 may be a promising novel therapy for treatment of hypertrophy in NSML patients. Additionally, Hahn and colleagues [14] reported the effects of treatment with a rapamycin analog in an infant with NSML and severe HCM.

In summary, we should avoid the misleading causative association between NSML-causing PTPN11 mutations and NS, based on the diverse impact of these mutations on SHP2 function and intracellular signaling dysregulation, and their consequent significance in terms of patient management and future personalized therapeutic options.

\section{Abbreviations \\ CHDs: Congenital cardiac defects; HCM: Hypertrophic cardiomyopathy; LVOTO: Left ventricular outflow tract obstruction; NS: Noonan syndrome; NSML: Noonan Syndrome with Multiple Lentigines}

\section{Acknowledgements}

We thank Dr. Elisa Del Vecchio for her valuable collaboration in the editorial revision.

\section{Authors' contributions}

All authors were involved in the initial conceptualization of this paper, providing critical input to the development of this manuscript. Finally, all authors were involved in the revision; they have read and approved the final manuscript. All authors take responsibility for all aspects of the reliability and freedom from bias of the data presented and their discussed interpretation.

\section{Funding}

No funding was given for this study.

\section{Availability of data and materials}

Not applicable.

\section{Ethics approval and consent to participate}

Not applicable.

\section{Consent for publication}

Not applicable.

\section{Competing interests}

The authors declare that they have no competing interests.

\section{Author details}

'Cardiology Unit, Department of Pediatric Cardiology and Cardiac Surgery, Bambino Gesù Children's Hospital and Research Institute, Viale di San Paolo 15, 00146 Rome, Italy. ${ }^{2}$ Genetics and Rare Diseases Research Division, Bambino Gesù Children's Hospital and Research Institute, Viale di San Paolo
15, 00146 Rome, Italy. ${ }^{3}$ Pediatric Cardiology, Department of Pediatrics, Sapienza University, Viale Regina Elena 324, 00161 Rome, Italy.

Received: 11 April 2019 Accepted: 28 June 2019

Published online: 05 July 2019

\section{References}

1. Chen H, Li X, Liu X, Wang J, Zhang Z, Wu J, Huang M, Guo Y, Li F, Wang X, Fu L. Clinical and mutation profile of pediatric patients with RASopathyassociated hypertrophic cardiomyopathy: results from a Chinese cohort. Orphanet J Rare Dis. 2019;14(1):29-019-1010-z.

2. Calcagni G, Limongelli G, D'Ambrosio A, Gesualdo F, Digilio MC, Baban A, Albanese SB, Versacci P, De Luca E, Ferrero GB, Baldassarre G, Agnoletti G, Banaudi E, Marek J, Kaski JP, Tuo G, Russo MG, Pacileo G, Milanesi O, Messina D, Marasini M, Cairello F, Formigari R, Brighenti M, Dallapiccola B, Tartaglia M, Marino B. Cardiac defects, morbidity and mortality in patients affected by RASopathies. CARNET study results. Int J Cardiol. 2017;245:92-8.

3. Calcagni G, Limongelli G, D'Ambrosio A, Gesualdo F, Digilio MC, Baban A, Albanese SB, Versacci P, De Luca E, Ferrero GB, Baldassarre G, Agnoletti G, Banaudi E, Marek J, Kaski JP, Tuo G, Russo MG, Pacileo G, Milanesi O, Messina D, Marasini M, Cairello F, Formigari R, Brighenti M, Dallapiccola B, Tartaglia M, Marino B. Data on cardiac defects, morbidity and mortality in patients affected by RASopathies. CARNET study results. Data Brief. 2017;16: 649-54.

4. Laredo M, Khraiche D, Raisky O, Gaudin R, Bajolle F, Maltret A, Chevret S, Bonnet D, Vouhe PR. Long-term results of the modified Konno procedure in high-risk children with obstructive hypertrophic cardiomyopathy. J Thorac Cardiovasc Surg. 2018;156(6):2285-94 e2.

5. Hanna N, Montagner A, Lee WH, Miteva M, Vidal M, Vidaud M, Parfait B, Raynal P. Reduced phosphatase activity of SHP-2 in LEOPARD syndrome: consequences for PI3K binding on Gab1. FEBS Lett. 2006;580(10):2477-82.

6. Noda S, Takahashi A, Hayashi T, Tanuma S, Hatakeyama M. Determination of the catalytic activity of LEOPARD syndrome-associated SHP2 mutants toward parafibromin, a bona fide SHP2 substrate involved in Wnt signaling. Biochem Biophys Res Commun. 2016;469(4):1133-9.

7. Schramm C, Fine DM, Edwards MA, Reeb AN, Krenz M. The PTPN11 loss-offunction mutation Q510E-Shp2 causes hypertrophic cardiomyopathy by dysregulating mTOR signaling. Am J Physiol Heart Circ Physiol. 2012;302(1): H231-43.

8. Tartaglia M, Martinelli S, Stella L, Bocchinfuso G, Flex E, Cordeddu V, Zampino G, Burgt I, Palleschi A, Petrucci TC, Sorcini M, Schoch C, Foa R, Emanuel PD, Gelb BD. Diversity and functional consequences of germline and somatic PTPN11 mutations in human disease. Am J Hum Genet. 2006; 78(2):279-90.

9. Kontaridis MI, Swanson KD, David FS, Barford D, Neel BG. PTPN11 (Shp2) mutations in LEOPARD syndrome have dominant negative, not activating, effects. J Biol Chem. 2006;281(10):6785-92.

10. Digilio MC, Sarkozy A, Pacileo G, Limongelli G, Marino B, Dallapiccola B. PTPN11 gene mutations: linking the GIn510Glu mutation to the "LEOPARD syndrome phenotype". Eur J Pediatr. 2006;165(11):803-5.

11. Digilio MC, Sarkozy A, de Zorzi A, Pacileo G, Limongelli G, Mingarelli R, Calabro R, Marino B, Dallapiccola B. LEOPARD syndrome: clinical diagnosis in the first year of life. Am J Med Genet A. 2006;140(7):740-6.

12. Lehmann LH, Schaeufele T, Buss SJ, Balanova M, Hartschuh W, Ehlermann P, Katus HA. IMAGE CARDIO MED. A patient with LEOPARD syndrome and PTPN11 mutation. Circulation. 2009;119(9):1328-9.

13. Ganigara M, Prabhu A, Kumar RS. LEOPARD syndrome in an infant with severe hypertrophic cardiomyopathy and PTPN11 mutation. Ann Pediatr Cardiol. 2011:4(1):74-6.

14. Hahn A, Lauriol J, Thul J, Behnke-Hall K, Logeswaran T, Schanzer A, Bogurcu N, Garvalov BK, Zenker M, Gelb BD, von Gerlach S, Kandolf R, Kontaridis MI, Schranz D. Rapidly progressive hypertrophic cardiomyopathy in an infant with Noonan syndrome with multiple lentigines: palliative treatment with a rapamycin analog. Am J Med Genet A. 2015;167A(4):744-51.

15. Takahashi K, Kogaki S, Kurotobi S, Nasuno S, Ohta M, Okabe H, Wada K, Sakai N, Taniike M, Ozono K. A novel mutation in the PTPN11 gene in a patient with Noonan syndrome and rapidly progressive hypertrophic cardiomyopathy. Eur J Pediatr. 2005;164(8):497-500.

16. Faienza MF, Giordani L, Ferraris M, Bona G, Cavallo L. PTPN11 gene mutation and severe neonatal hypertrophic cardiomyopathy: what is the link? Pediatr Cardiol. 2009;30(7):1012-5. 
17. Derbent M, Oncel Y, Tokel K, Varan B, Haberal A, Yazici AC, Legius E, Ozbek N. Clinical and hematologic findings in Noonan syndrome patients with PTPN11 gene mutations. Am J Med Genet A. 2010;152A(11):2768-74.

18. Keren B, Hadchouel A, Saba S, Sznajer Y, Bonneau D, Leheup B, Boute O, Gaillard D, Lacombe D, Layet V, Marlin S, Mortier G, Toutain A, Beylot C, Baumann C, Verloes A, Cave H, Collaborative F. Noonan study group: PTPN11 mutations in patients with LEOPARD syndrome: a French multicentric experience. J Med Genet. 2004;41(11):e117.

19. Kalidas K, Shaw AC, Crosby AH, Newbury-Ecob R, Greenhalgh L, Temple IK, Law C, Patel A, Patton MA, Jeffery S. Genetic heterogeneity in LEOPARD syndrome: two families with no mutations in PTPN11. J Hum Genet. 2005; 50(1):21-5.

20. Brasil AS, Pereira AC, Wanderley LT, Kim CA, Malaquias AC, Jorge AA, Krieger JE, Bertola DR. PTPN11 and KRAS gene analysis in patients with Noonan and Noonan-like syndromes. Genet Test Mol Biomarkers. 2010;14(3):425-32

21. Wakabayashi Y, Yamazaki K, Narumi Y, Fuseya S, Horigome M, Wakui K, Fukushima Y, Matsubara Y, Aoki Y, Kosho T. Implantable cardioverter defibrillator for progressive hypertrophic cardiomyopathy in a patient with LEOPARD syndrome and a novel PTPN11 mutation GIn510His. Am J Med Genet A. 2011;155A(10):2529-33.

22. Digilio MC, Lepri F, Baban A, Dentici ML, Versacci P, Capolino R, Ferese R, De Luca A, Tartaglia M, Marino B, Dallapiccola B. RASopathies: clinical diagnosis in the first year of life. Mol Syndromol. 2011;1(6):282-9.

23. Nakamura T, Gulick J, Pratt R, Robbins J. Noonan syndrome is associated with enhanced pERK activity, the repression of which can prevent craniofacial malformations. Proc Natl Acad Sci U S A. 2009:106(36):15436-41.

24. Krenz M, Yutzey KE, Robbins J. Noonan syndrome mutation Q79R in Shp2 increases proliferation of valve primordia mesenchymal cells via extracellular signal-regulated kinase 1/2 signaling. Circ Res. 2005;97(8):813-20.

25. Marin TM, Keith K, Davies B, Conner DA, Guha P, Kalaitzidis D, Wu X, Lauriol J, Wang B, Bauer M, Bronson R, Franchini KG, Neel BG, Kontaridis Ml. Rapamycin reverses hypertrophic cardiomyopathy in a mouse model of LEOPARD syndrome-associated PTPN11 mutation. J Clin Invest. 2011;121(3): 1026-43.

26. Wang J, Chandrasekhar V, Abbadessa G, Yu Y, Schwartz B, Kontaridis MI. In vivo efficacy of the AKT inhibitor ARQ 092 in Noonan syndrome with multiple lentigines-associated hypertrophic cardiomyopathy. PLoS One. 2017;12(6):e0178905.

\section{Publisher's Note}

Springer Nature remains neutral with regard to jurisdictional claims in published maps and institutional affiliations.

Ready to submit your research? Choose BMC and benefit from:

- fast, convenient online submission

- thorough peer review by experienced researchers in your field

- rapid publication on acceptance

- support for research data, including large and complex data types

- gold Open Access which fosters wider collaboration and increased citations

- maximum visibility for your research: over $100 \mathrm{M}$ website views per year

At $\mathrm{BMC}$, research is always in progress.

Learn more biomedcentral.com/submissions 